\title{
Predicting the Quality of Work Life of Librarians in Public Libraries Based on Organizational Justice Dimensions
}

\author{
Parvin Jahangiri \\ Hamadan University of Medical Sciences, Hamadan, Iran \\ jhangiry713@gmail.com \\ Leila Hashempour \\ Department of Information Management, \\ Hacettepe University, Ankara, Turkey \\ leila_hashempour@yahoo.com \\ Bahram Heshmati \\ Medical Journalism Department, Paramedical School, \\ University of Medical Sciences, Shiraz, Iran \\ heshmati.bahram@gmail.com
}

Mohammad Karim Saberi (corresponding author)

Department of Medical Library and Information Sciences, School of Paramedicine Hamadan University of Medical Sciences, Hamadan, Iran mohamadsaberi@gmail.com

\begin{abstract}
Background. Human resources are considered the most significant assets of any organization. Improving the quality of work life will motivate employees to provide quality services.

Objective. This study investigated the extent to which organizational justice and its dimensions affect perception of the quality of work life among librarians working in the public libraries of Iran. Organizational justice refers to employees' apprehension of the extent that management's actions and decisions are fair and equitable.

Method. Two questionnaires derived from Walton's (1973) Quality of Work Life questionnaire, and Niehoff and Moorman's (1993) Organizational Justice questionnaire were used to determine public librarians' perceptions of the quality of work life and various aspects of organizational justice in the workplace. Results. Pearson correlation results indicate that quality of work life had a positive and significant association with all the dimensions of organizational justice, including distributive justice $(\mathrm{r}=0.62)$, procedural justice $(\mathrm{r}=0.21)$, and interactional justice $(\mathrm{r}=0.16)$.

Contributions. The results indicate a fairly strong impact of distributive organizational justice on librarians' perception of the quality of work life. It is recommended that public library administrators pay more attention to organizational justice in the workplace, especially distributive justice which refers to the fair allocation of financial and non-financial resources.
\end{abstract}




\section{INTRODUCTION}

Quality of work life is a concept that emerged in the second half of the 20th century in management and organization as a contributing and influential factor in enhancing employee productivity (Anyaoku, 2016; Hart, 2010; Mirkamali \& Narenji, 2008).

Libraries, particularly public libraries, play a large role in the social, cultural, and political development of human societies. Librarians in public libraries are important human resources essential to the success, mission, as well as the accomplishment of public library goals. Consequently, it is important to study issues that impact on the effectiveness of public librarians (Koontz \& Gubbin, 2010; Saberi \& Babalhaveji, 2018). Anyaoku (2016) found that the quality of work life of librarians had a big impact on the performance of librarians working in various library types in Nigeria.

A review of the literature suggests that the term quality of work life was first used in the late 1960s by a General Motors employee named Irving Bluestone (Goode, 1989). It was the first work quality program in the United States that allowed employees to play an active role in making decisions about their working conditions. The program strived mainly to evaluate the level of job satisfaction of employees in order to formulate and develop programs that would increase employee productivity (Fernandes et al., 2017). Quality of work life is a concept that has attracted the attention of many scholars in recent decades, and has become an important social issue all over the world today. This concept implies seeking new ways to balance work and personal life (Imani, Karamporian \& Hamidi, 2014).

Quality of work life is defined as any type of activity carried out at the organization level that seeks greater organizational effectiveness through the growth and promotion of human dignity. Quality of work life can be defined as the quality of communication between employees and everybody in the workplace, such as managers. This term is used to describe the working conditions and expectations of most employees in their work lives (Anyaoku, 2016; Aziz et al., 2011). Walton (1973) defined eight components for explaining the quality of work life as described below (Fernandes et al., 2017):

1. Adequate income and fair compensation: One of the primary incentives for working is to meet financial needs which will in turn have an impact on the quality of work life. This concept implies that each individual is entitled to adequate and appropriate income so that he or she meets every-day needs in life (Detoni, 2001; Timossi et al., 2009).

2. Safe and healthy working conditions: Healthy and safe working conditions have a significant relationship with the quality of work life of employees. This means that employees should not be exposed to working conditions with adverse physical and psychological effects. Rules that make optimum and favorable working conditions by eliminating redundant factors, adequate lighting, preventing accidents by operating reasonable hours, etc., are therefore, necessary in this regard (Kheradmand et al., 2010).

3. Immediate opportunity to use and develop human capacities: This encompasses a variety of opportunities for employees such as independence at work and access to information related to their work. The experience of a strong and high quality of work life depends to a large extent on the extent to which businesses allow employees to employ their talents and abilities. Thus, occupations that involve multiple talents are more meaningful to their employees, and therefore there is a great incentive toward occupations that require more than two types of skills for each individual (Fernandes et al., 2017).

4. Opportunity for continued growth and security: This emphasizes the career advancement of employees, and indicates the creation of meaningful and satisfying work. Therefore, 
there should be a favorable environment for employees to develop their abilities and skills. Employees love to grow in the workplace where their talents can flourish (Detoni, 2001; Timossi et al., 2009).

5. Social integration in the work organization: This reflects a sense of shared belonging to the organization. This is related to the component of organizational commitment. Integrity and social cohesion refer to the extent people in the organization feel empathetic and belonging to each other, and the extent the organization has created a sense of belonging for them (Kheradmand et al., 2010).

6. Constitutionalism in the work organization: This refers to providing the conditions for employees at all levels of the organization to offer opinions without fear of the authority or officials, and to comment on issues related to the organization. This component includes cases that are of a legal nature, and indicate what rights and entitlements people have in the workplace (Walton, 1973; Fernandes, 1996).

7. Work and the total life space: This refers to the balance between work life and other aspects of employees' personal lives. This dimension represents a balance between the role that includes work, the work schedule, the role demands and career requirements that do not take up relief and times with family. In addition, the balance mentions development and progression (Fernandes et al., 2017).

8. Social relevance of work life: There has been much debate on the social relevance of work life. As such, the beneficial social roles of the organization and their activities have increasingly become a key issue for employees. Thus, it is understood that organizations that do not feel their social responsibilities provide a negative effect on the value of their employees' work and careers, which provide a basis for their sense of self-esteem. (Detoni, 2001; Timossi et al., 2009).

Given the importance of the quality of work life of librarians in public libraries, the purpose of this study was to predict the quality of work life of librarians through the dimensions of organizational justice.

\section{LITERATURE REVIEW}

In this section, organizational justice, its dimensions, its importance, and its relation with quality of work life are discussed. A few studies related to the quality of work life of librarians in some countries are also covered. In these studies, the relationship between demographic, work and non-work variables, and the quality of work life of specialists and librarians were examined.

Justice is a main issue for comprehension of organizational behavior (Bos, 2002). In recent years, the issue of fairness has been examined from the perspective of different disciplines, including law, economics, psychology, and organizational science (Dulebohn et al., 2009). Elanain (2010, p. 6) described organizational justice as a dominant theme in organizational life. Organizational justice deals with employee understanding of fairness and equity in the workplace (Rupp \& Thornton-Lugo, 2017). The term organizational justice can refer to employees' apprehension of the extent to which management's actions and decisions are fair, and also can affect their attitude toward management.

Organizational justice has three dimensions which are called procedural, distributive, and interactional justice, which are interrelated and form the entire organizational fairness system (Tan \& Yusof, 2016). Procedural justice refers to employees' perception of the 
fairness of management policies and methods that regulate a process resulting in decision outcomes. Distributive justice is described as fairness associated with decisions connected to the dispersion of financial or non-financial resources in an organization. Interactional justice is described as the right treatment that an employee takes as the consequence of managerial decision (Colquitt, 2001; Cropanzano \& Molina, 2015).

Organizational justice is significant from three considerations: economic, social, and ethical consideration. Employees need funds to maintain their quality of life. So, the willingness of employees to stay with an organization is often appropriate to the compensation received from their employer. Internal behaviors in the organization should have the power to show that employees are not abused, not only by the management but also by their co-workers, peers and so on. Justice is essential to have a sense of trust among them and the organization. Employers have the ethical responsibility to provide fair pay to employees. Thus, they are very attentive about equitable salaries. They think management decisions should be just and they must treat fairly (Tan \& Yusof, 2016; Milkovich \& Newman, 2005).

Various studies have shown that there is a relationship between quality of work life and organizational justice, and that organizational justice can account for quality of work life of employees (Moghimi et al., 2013; Nishtar \& Ralston, 2013; Shakoorzadeh et al., 2015; Arefi et al., 2015; Hartini et al., 2017). When employees feel that they work in an organization where principles of justice are not observed, they will find themselves in a condition of perceptual-affective strain. Consequently, if principles of justice are violated in the organization, employees will encounter job dissatisfaction, lack of commitment, and lack of motivation in long run (Nelson \& Tarpey, 2010). In other words, if employees feel injustice, they will be adversely influenced in terms of spirit, performance, and dimensions of quality of work life. Indeed, justice is realized in an organization if and only if incentives, punishments, and resources designated for each of them are considered proportionate to their individual share (Cropanzano \& Greenberg, 1997). Studies in the field of library and information science mainly examined these variables individually. These studies are mentioned below.

Reena (2009) investigated the relationship between demographic variables and quality of work life and job stress of 300 specialists in the field of library and information science in the state of Kerala, India. The results showed a significant relationship was found between quality of work life and three independent variables including library size in terms of number of books, professional experiences, and job position. Also, a significant relationship was observed between quality of work life and three independent variables, such as library size in terms of number of employees, age, and involvement with IT tools. According to the results the relationship between quality of work life and job stress using the chi-square test and Pearson correlation coefficient was investigated and it was determined that there was a significant relationship between these two variables.

Aziz et al. (2011) examined the relationship between work and non-work variables with the quality of work life of librarians. In their study, the librarians of government university libraries in Klang Valley, Malaysia were selected as the study sample. The results of the survey study indicated that both work variables (such as workload, work environment) as well as non-work variables (quality of family life, number of children, sex, age, etc.) were involved in determining the quality of employees' quality of work and that the relationship among them was significant. Furthermore, the findings of their study revealed that human resources and their motivational issues in the workplace were very important. Accordingly, managers should take into consideration the amelioration of their employees' conditions and quality of work life as a valuable tool in this respect. 
Anyaoku (2016), examined the quality of work life of 175 Nigerian librarians. The Quality of Work Life scale was used in this study. The results showed that the quality of work life of librarians in the fields of opportunity for continued growth and security, social integration in the work organization, and social relevance of work was relatively high. Though the quality of work life of the librarians was poor in areas like fair remuneration, training and retraining, provision for job performance and equal right. The results of statistical tests showed that there was a significant relationship between quality of work life and gender, age, institution type and years of work experience. However, it had no relationship with educational qualification.

Koohbanani et al. (2019) addressed the quality of work life of librarians in Iranian public libraries. The standard questionnaire of Walton (1973) was used in this survey study. The findings showed that the dimensions of organizational social integration, constitutionalism in the organization and the capacity for human development are at a good level; the dimensions of the environment opportunity for continued growth and security and safe and healthy work are at a moderate level. Finally, the dimensions of fair and adequate payment, social relevance of work life and total life space at a weak level are shown.

All these studies have examined the quality of work life of librarians, and the relationship between this subject with various variables. The quality of work life of librarians based on organizational justice was not discussed. Accordingly, the present study sought to predict the quality of work life of public librarians through organizational justice and its dimensions.

\section{METHODOLOGY}

In this survey study, two questionnaires were used. They were adapted from Walton's (1973) Quality of Work Life questionnaire, and Neihoff and Moorman's (1993) Organizational Justice questionnaire. The former has 32 items with a 5-point Likert-like scale (very little, little, to some extent, much, very much). The eight components of this questionnaire as well as the number of items for each component are listed in Table 1. Walton (1973) reported a Cronbach alpha of 0.88 for the reliability of the questionnaire. The Organizational Justice (Neihoff \& Moorman, 1993) questionnaire encompasses 20 items under the three sections of distributive justice, procedural justice, and interactional justice. The number of items for each component is given in Table 1. In this questionnaire, a 5-point Likert scale (1-completely disagree, 2-disagree, 3-no idea, 4-agree, and 5-completely agree) was used. The authors reported a reliability coefficient of 0.85 .

The validity of the questionnaires was assessed using the opinions of experts in the fields of management and library and information sciences since the purpose of the study was to evaluate the use of two important topic of management in libraries. Cronbach's alpha coefficient was calculated to evaluate the reliability of the questionnaires. The coefficient for the questionnaires was greater than 0.80 , indicating appropriate reliability of the research instruments.

The study population consisted of about 7,000 librarians in about 3,500 public libraries all around Iran. Running William Cochran's (1931) formula (with 95\% confidence interval and p-value of 0.05 , and assuming simple random sampling), a target sample size of 365 was determined. 440 questionnaires were distributed, and 379 completed questionnaires were collected. Based on initial data screening, 365 questionnaires were identified as appropriate for statistical analysis. The data analyses performed were mainly Pearson correlation and oneway ANOVA $(\alpha<0.01)$, using the SPSS statistical software (version 25). 
Table 1. Components of quality of work life questionnaire and organizational justice questionnaire

\begin{tabular}{|c|c|c|c|c|c|}
\hline \multicolumn{4}{|c|}{$\begin{array}{l}\text { Quality of work life questionnaire } \\
\text { (see Appendix 1) }\end{array}$} & \multicolumn{2}{|c|}{$\begin{array}{c}\text { Organizational justice } \\
\text { questionnaire } \\
\text { (see Appendix 2) }\end{array}$} \\
\hline $\begin{array}{l}\text { Adequate income and } \\
\text { fair compensation }\end{array}$ & 1 to 5 & $\begin{array}{l}\text { Social relevance of } \\
\text { work life }\end{array}$ & 18 to 20 & Distributive justice & 1 to 5 \\
\hline $\begin{array}{l}\text { Safe and healthy } \\
\text { working conditions }\end{array}$ & 6 to 8 & $\begin{array}{l}\text { Work and the total life } \\
\text { space }\end{array}$ & 21 to 25 & Procedural justice & 6 to 11 \\
\hline $\begin{array}{l}\text { Opportunity for } \\
\text { continued growth and } \\
\text { security }\end{array}$ & 9 to 11 & $\begin{array}{l}\text { Social integration in the } \\
\text { work organization }\end{array}$ & 26 to 29 & Interactional justice & 12 to 20 \\
\hline $\begin{array}{l}\text { Constitutionalism in } \\
\text { work organization }\end{array}$ & 12 to 17 & $\begin{array}{l}\text { Immediate opportunity } \\
\text { to use and develop } \\
\text { human capacities }\end{array}$ & 30 to 32 & & \\
\hline
\end{tabular}

Table 2. Respondents' demographic information

\begin{tabular}{|c|c|c|c|}
\hline Measure & Items & Frequency & Percentage \\
\hline \multirow{2}{*}{ Gender } & Male & 157 & 43.01 \\
\hline & Female & 208 & 56.99 \\
\hline \multirow{4}{*}{ Age } & $18-24$ years & 34 & 9.32 \\
\hline & $25-34$ years & 196 & 53.70 \\
\hline & $35-45$ years & 123 & 33.70 \\
\hline & 45 years and above & 12 & 3.29 \\
\hline \multirow{6}{*}{ Work experience } & $1-4$ years & 78 & 21.37 \\
\hline & $5-9$ years & 134 & 36.71 \\
\hline & 10-14 years & 68 & 18.63 \\
\hline & $15-19$ years & 36 & 9.86 \\
\hline & 20-24 years & 28 & 7.67 \\
\hline & 25 years and over & 21 & 5.75 \\
\hline \multirow{4}{*}{ Level of education } & Diploma & 24 & 6.58 \\
\hline & Associate of art & 37 & 10.14 \\
\hline & Bachelors & 190 & 52.05 \\
\hline & Master of art and higher & 114 & 31.23 \\
\hline
\end{tabular}

\section{FINDINGS}

Table 2 shows the details of the respondents' demographic profiles. Of the 365 respondents, the majority were female ( $\mathrm{n}=208,57 \%)$. In terms of age, the highest number of respondents was between 25-34 years old $(n=196,54 \%)$ and the lowest number of respondents was 45 years old and above $(n=12,3 \%)$. In terms of work experience, the majority of respondents 
$(\mathrm{n}=134,37 \%)$ reported work experience of between 5 and 9 years. The level of education of most librarians participating in this study was Bachelor's degree $(n=190,52 \%)$.

The results of Pearson correlation coefficient are given in Table 3, below. The results indicate a significant positive correlation with distributive justice $(\mathrm{r}=0.62)$, procedural justice $(\mathrm{r}=0.21)$, and interactional justice $(\mathrm{r}=0.16)$. Given the results of Pearson correlation, it can be said that an increase in the dimensions of organizational justice, that is, distributive, procedural, and interactional justice will result in an increase in the quality of life of librarians in public libraries.

The results of the Multiple Linear Regression are presented in Table 4. As can be seen in Table 5, among the dimensions of organizational justice entered into regression model, only distributive justice remained in the model and that other components removed from the model. Given the obtained results, the relationship between quality of work life and distributive justice is significant $(\beta=0.62)$. Overall, the variable, distributive justice, accounted for $41 \%$ of changes in the quality of work life of librarians. In addition, the results of the multiple regression analysis indicated that the regression analysis model enjoyed a good fitness $(\mathrm{F}=171.43, \mathrm{p}<0.01)$.

\section{DISCUSSION AND CONCLUSION}

Undoubtedly, skilled and efficient staffing is one of the most important tools to achieve the goals and objectives of libraries, and the rate of librarians' quality of work life has a major impact on the quality of library services. As is the case with librarians when it comes to hiring librarians, there is a need for appropriate conditions for librarians to work after they are hired. Otherwise, librarians will become marginalized and burn out which will in turn have an adverse effect on the quality of service provided by librarians.

The purpose of this study was to examine the relationship between the quality of work life of librarians in public libraries and organizational justice. The results of the study revealed a positive and significant relationship between the quality of work life of the librarians and the dimensions of organizational justice including distributive justice $(\mathrm{r}=0.62)$, procedural justice $(\mathrm{r}=0.21)$ and procedural justice $(\mathrm{r}=0.16)$. Accordingly, it can be said that along with an increase in organizational justice in public libraries, the quality of work life of librarians will also be increased. This finding is in line with that of the study by Aminbeidokhti and Mardani (2014). They looked at the relationship between organizational justice and the quality of work life of employees in a hospital in Ahvaz, Iran. Their results showed that there was a positive and significant relationship between the organizational justice (distributive and procedural) and the quality of work life of the employees. To explain this finding, it should be noted that the quality of work life is influenced by factors such as office hours, inadequate facilities, inadequate closing hours, managerial practices, lack of adequate opportunity for progress, unfavorable working condition, shortage of staff, and low level of income (Arefi et al., 2015). Also, the most important indicators of quality of work life include: income and facilities, work schedule, nature of work, physical aspects, internal and external symbolic aspects, and political, social, and economic factors which contribute to life (Khadive \& Aliee, 2007). Accordingly, it is recommended that library managers, especially those in public libraries, pay particular attention to these indicators and strive to manage librarians by managing the working hours of librarians, giving librarians adequate rest and providing them with opportunities for career advancement and promotion.

The results of multiple regression analysis were indicative of the relationship between one of the components of organizational justice and the quality of work life of the librarians. 
Of these, distributive justice accounted for $41 \%$ of variance in the quality of work life of librarians in public libraries. These findings are in line with the findings by Yoosefi (2014) and Gillet et al. (2013). In order to explain this finding, it should be noted that the perception of unfair interactions, payments and procedures can lead to negative behavioral and mental consequences such as recentness, violence, anxiety as well as the considerable decline of dimensions of quality of work life and effectiveness of employee communications (Lambert, 2003).

The perception of injustice results in reduction in trust, motivation, satisfaction, and organizational deviant behaviors which will have an adverse effect on the effectiveness of leadership style and quality of work life of employees (Folger \& Cropanzano, 1998). All said, it is recommended that managers and authorities in libraries, in particular public libraries, pay particular attention to three principles of fairness, need, and equality which are the basis and pillar for distributive justice. The principle of fairness states that people should receive incentives in accordance with their effort, while the principle of equality emphasizes that all people should be given equal chances to accomplish the results or incentives regardless of the differences in capabilities. Eventually, the principle of need states that incentives must be distributed based on people's needs. As a result, special consideration is that the persons in need must be identified and subvention must be paid to them and this is the same justice. Therefore, observing these principles which are the bases of distributive justice can ameliorate the quality of work life of librarians.

\section{FUNDING}

The study was funded by the Vice-Chancellor for Research and Technology, Hamadan University of Medical Sciences (No. 9905073011).

\section{REFERENCES}

Aziz, A.R., Nadzar, F.M., Husaini, H., Maarof, A., Radzi, S.M., \& Ismail, I. (2011). Quality of work life of librarians in government academic libraries in the Klang Valley, Malaysia. The International Information \& Library Review, 43(3), 149-158.

Aminbeidokhti A.A, \& Mardani E. (2014). The relationship between perceived organizational justice and quality of work life among the personnel of a selected hospital in Ahvaz. Journal of Medical Ethics History Medicine, 7(2), 57-68.

Anyaoku, E.N. (2016). Demographic determinants of quality of work life of librarians working in Nigeria. International Journal of Advanced Library and Information Science, 4(1), 312-323.

Arefi M., Khorsandi A., \& Ghahramani M. (2015). The identify the relationship between organizational justice and quality of work life and the mediating role of organizational culture from the point of view of employees at Shahid Beheshti University. Quarterly Journal Career \& Organizational Counseling, 7(23), 41-67.

Bos, K.V. (2002). Assimilation and contrast in organizational justice: The role of primed mindsets in the psychology of the fair process effect. Organizational Behavior and Human Decision Processes, 89(1), 866-880.

Colquitt, J.A. (2001). On the dimensionality of organizational justice: A construct validation of a measure. Journal of Applied Psychology, 86(3), 386-400.

Cropanzano, R., \& Greenberg, J. (1997). Progress in organizational justice: Tunneling through the maze. International Review of Industrial and Organizational Psychology, $12,317-372$. 
Cropanzano, R., \& Molina, A. (2015). Organizational justice. In International encyclopedia of the social \& behavioral sciences ( $2^{\text {nd }}$ ed., pp. 379-384). Elsevier.

Detoni, D.J. (2001). Estratégias de avaliação da qualidade de vida no trabalho (Dissertação de mestrado). Universidade Federal de Santa Catarina, Florianópolis, PR, Brasil.

Dulebohn, J.H., Conlon, D.E., Sarinopoulos, I., Davison, R.B., \& McNamara, G. (2009). The biological bases of unfairness: Neuroimaging evidence for the distinctiveness of procedural and distributive justice. Organizational Behavior and Human Decision Processes, 110(2), 140-151.

Elanain, H.M.A. (2010). Testing the direct and indirect relationship between organizational justice and work outcomes in a non-Western context of the UAE. Journal of Management Development, 29(1), 5-27.

Tan, F.Y., \& Yusof, A.A. (2016). Organizational justice: A conceptual discussion. ProcediaSocial and Behavioral Sciences, 219, 798-803.

Fernandes, E.C. (1996). Qualidade de vida no trabalho: Como medir para melhorar. Casa da Qualidade, Salvador.

Fernandes, R.B., Martins, B.S., Caixeta, R.P., \& Antonialli, L.M. (2017). Quality of work life: An evaluation of Walton model with analysis of structural equations. Espacios, $38(03)$.

Folger, R.G., \& Cropanzano, R. (1998). Organizational justice and human resource management. Sage.

Gillet, N., Fouquereau, E., Bonnaud-Antignac, A., Mokounkolo, R., \& Colombat, P. (2013). The mediating role of organizational justice in the relationship between transformational leadership and nurses' quality of work life: A cross-sectional questionnaire survey. IJNS, 50(10), 1359-67.

Goode, D.A. (1989). Quality of life, quality of work life. In W.E. Kiernan \& R.L. Schalock (Eds.), Economics, industry and disability: A look ahead (pp. 337-349). Paul H. Brookes.

Hart, G. (2010). Job satisfaction in a South African academic library in transition. The Journal of Academic Librarianship, 36(1), 53-62.

Hartini, M., Haerani, H., Mardiana, R., \& Sumardi, F. (2017). The influences of quality of work life and organizational justice on the employees performance of the state-owned enterprises (SOEs) in South Sulawesi. SciRJ, 5(3), 1-8.

Imani, B., Karamporian, A., \& Hamidi, Y. (2014). The relationship between quality of work life and job stress in employees the foundation of martyrs and veterans' affairs of Hamadan. Journal Mil Med, 15(4), 253-257.

Khadivi, A, \& Aliee, H. (2007). Study of the quality of work life of the employees of Islamic Azad University of Tabriz Branch. JMS, 1(2), 150-72.

Koontz, C., \& Gubbin, B. (Eds.) (2010). IFLA public library service guidelines ( $\left.2^{\text {nd }} \mathrm{ed}.\right)$. Walter de Gruyter.

Kheradmand, E., Valilu, M., \& Lotfi, A. (2010). The relationship between quality of work life and job performance. Middle East Journal of Scientific Research, 4(6), 317-323.

Koohbanani, H.K., Zarei, A., \& Erfani, N. (2019). Measuring the librarians' quality of work life in the Iranian public libraries. Library Management, 40(8/9), 532-542.

Lambert E. (2003). The impact of organizational justice on correctional staff. Journal of Criminal Justice, 31(2), 155-68.

Milkovich, G.T., \& Newman, J.M. (2005). Compensation ( $8^{\text {th }}$ ed.). McGraw-Hill. 
Mirkamali, S.M., \& Narenji, S.F. (2008). A study on the relationship between the quality of work life and job satisfaction among the faculty members of the University of Tehran and Sharif University of Technology. IRPHE, 14(2), 71-101.

Moghimi S.M, Kazemi M, \& Samiie S. (2013). Studying the relationship between organizational justice and employees' quality of work life in public organizations: A case study of Qom province. IJMS, 6(1), 117-43.

Niehoff, B.P., \& Moorman, R.H. (1993). Justice as a mediator of the relationship between methods of monitoring and organizational citizenship behavior. Academy of Management Journal, 36(3), 527-556.

Nelson, M.F., \& Tarpey, R.J. (2010). Work scheduling satisfaction and work life balance for nurses: The perception of organizational justice. Academy of Health Care Management Journal, 6(1), 25.

Nishtar, S., \& Ralston, J. (2013). Can human resources for health in the context of noncommunicable disease control be a lever for health system changes? Bulletin of the World Health Organization, 91, 895-896.

Reena, K. K. (2009). Quality of work life and occupational stress among the library professional in Kerala [Unpublished doctoral dissertation]. University of Calicut.

Rupp, D., \& Thornton-Lugo, M. (2017). Organizational justice. Oxford Bibliographies. https://www.oxfordbibliographies.com/view/document/obo-9780199828340/obo9780199828340-0044.xml

Saberi, M.K. \& Babalhaveji, F. (2018). Intrapreneurship in public libraries: An exploratory and confirmatory factor analysis. Library Philosophy and Practice (e-journal), 1707. https://digitalcommons.unl.edu/libphilprac/1707

Shakoorzadeh, R., Vaisi, R., Maheri, S., Ebadi, S., \& Dolatshah, Z. (2015). Survey of relationship between organizational justice and staff's efficiency in education factory in the city of Urmia. Indian Journal of Science and Technology, 8(12), 1.

Timossi, L. da L., Pedroso, B., Pilatti, L.A., \& Francisco, A.C. de. (2009). Adaptação do modelo de Walton para avaliação da qualidade de vida no trabalho. Journal of Physical Education, 20(3), 395-405.

Walton, R.E. (1973). Quality of work life: What is it? Sloan Management Review, 15(1), 1121.

Yoosefi S. (2014). The relationship between perceived organizational justice and organizational trust with quality of work life from the viewpoint of employees of Razi University of Kermanshah in the academic year 2013-2014 [Unpublished Master's thesis]. Bu-Ali Sinai University of Hamedan. 
APPENDIX 1. QUALITY OF WORK LIFE QUESTIONNAIRE

\begin{tabular}{|c|c|c|c|c|c|c|}
\hline No. & Questions & $\begin{array}{l}\bar{e} \\
\stackrel{\Xi}{\Xi} \\
\stackrel{0}{0} \\
\nu\end{array}$ & $\stackrel{\Xi}{\stackrel{e}{e}}$ & 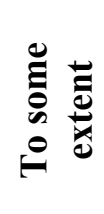 & 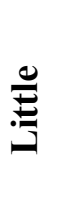 & 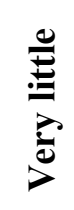 \\
\hline 1 & $\begin{array}{l}\text { To what extent does your salary from the public } \\
\text { library match your criteria? }\end{array}$ & & & & & \\
\hline 2 & $\begin{array}{l}\text { To what extent is the payroll system of public library } \\
\text { librarians compatible with other payroll systems? }\end{array}$ & & & & & \\
\hline 3 & $\begin{array}{l}\text { How satisfied are you with your salary from the } \\
\text { Public Library? }\end{array}$ & & & & & \\
\hline 4 & How much is your salary be paid on time? & & & & & \\
\hline 5 & $\begin{array}{l}\text { To what extent do your public library salaries cover } \\
\text { your living expenses? }\end{array}$ & & & & & \\
\hline 6 & $\begin{array}{l}\text { How satisfied are you with the physical and work } \\
\text { environment of the public library? }\end{array}$ & & & & & \\
\hline 7 & $\begin{array}{l}\text { How safe is your work environment in terms of } \\
\text { safety and health? }\end{array}$ & & & & & \\
\hline 8 & $\begin{array}{l}\text { How satisfied are you with your working hours in the } \\
\text { public library? }\end{array}$ & & & & & \\
\hline 9 & $\begin{array}{l}\text { To what extent does your job allow you to grow your } \\
\text { potential? }\end{array}$ & & & & & \\
\hline 10 & $\begin{array}{l}\text { To what extent is it possible for you to use the skills } \\
\text { learned? }\end{array}$ & & & & & \\
\hline 11 & $\begin{array}{l}\text { To what extent is there job security in the public } \\
\text { library? }\end{array}$ & & & & & \\
\hline 12 & To what extent do managers treat librarians fairly? & & & & & \\
\hline 13 & $\begin{array}{l}\text { To what extent do librarians have the opportunity to } \\
\text { freely express their views without fear of library } \\
\text { administrators? }\end{array}$ & & & & & \\
\hline 14 & $\begin{array}{l}\text { To what extent do librarians in public libraries have } \\
\text { free thinking? }\end{array}$ & & & & & \\
\hline 15 & $\begin{array}{l}\text { To what extent are librarians provided with a } \\
\text { codified method to comment on or complain about } \\
\text { an issue? }\end{array}$ & & & & & \\
\hline 16 & $\begin{array}{l}\text { To what extent are the regulations in public libraries } \\
\text { satisfactory for librarians? }\end{array}$ & & & & & \\
\hline 17 & $\begin{array}{l}\text { To what extent are the problems of librarians solved } \\
\text { in public libraries according to the principles and } \\
\text { rules? }\end{array}$ & & & & & \\
\hline 18 & $\begin{array}{l}\text { To what extent do library administrators of public } \\
\text { libraries respect the laws of society? }\end{array}$ & & & & & \\
\hline 19 & $\begin{array}{l}\text { To what extent do public library administrators } \\
\text { comply with the rules and regulations governing } \\
\text { public libraries? }\end{array}$ & & & & & \\
\hline
\end{tabular}




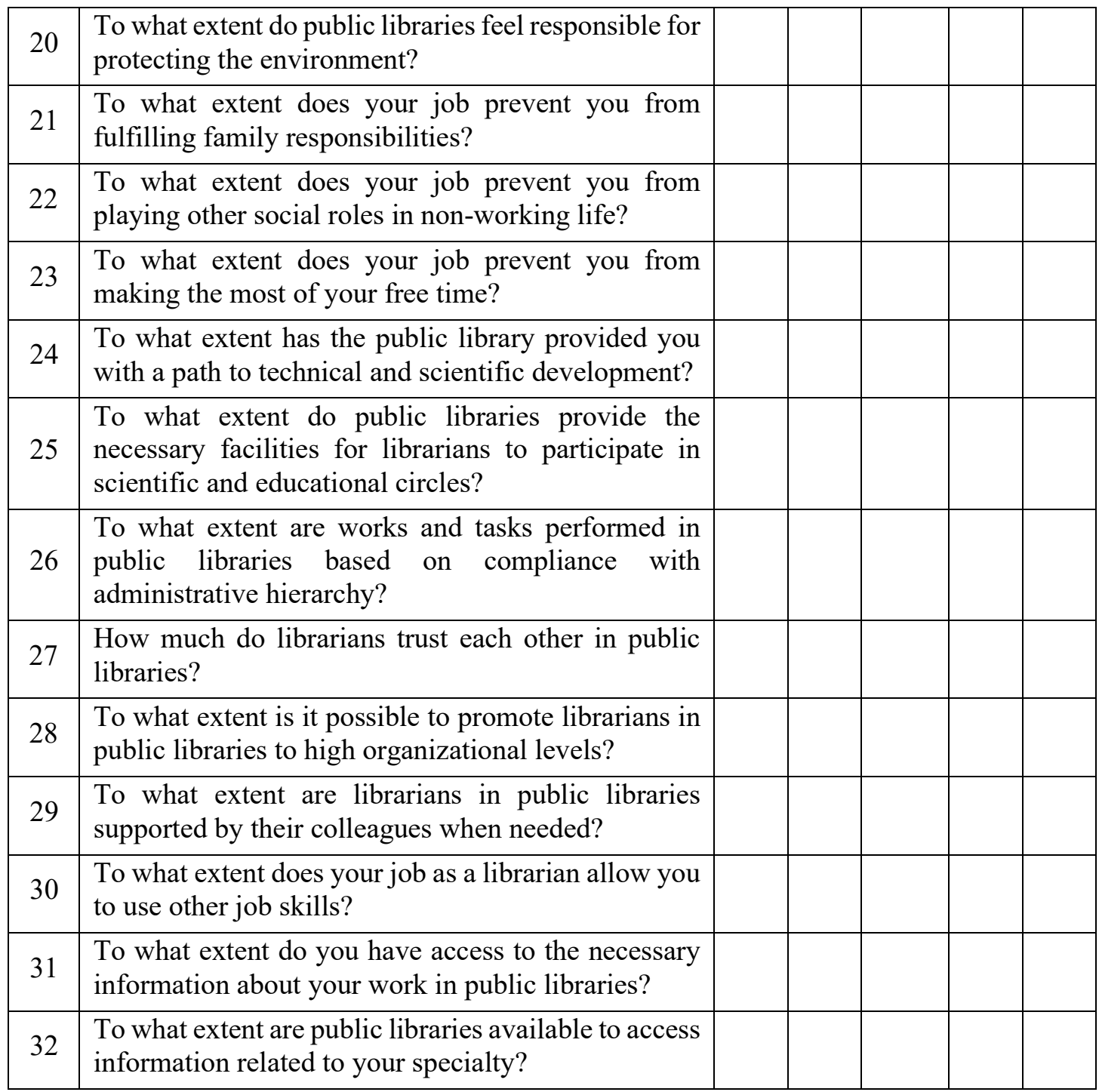


APPENDIX 2. ORGANIZATIONAL JUSTICE QUESTIONNAIRE

\begin{tabular}{|c|c|c|c|c|c|c|}
\hline No. & Questions & 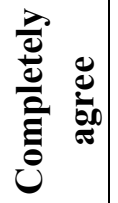 & 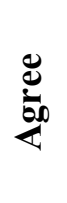 & $\frac{\mathfrak{g}}{\stackrel{0}{*}}$ & 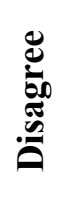 & 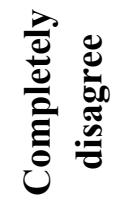 \\
\hline 1 & I think my work schedule in the public library is fair. & & & & & \\
\hline 2 & I think the level of my salary in the public library is fair. & & & & & \\
\hline 3 & I find the workload in the public library quite fair. & & & & & \\
\hline 4 & $\begin{array}{l}\text { All in all, the rewards I receive in the public library are } \\
\text { fair. }\end{array}$ & & & & & \\
\hline 5 & $\begin{array}{l}\text { I feel that my job responsibilities in the public library are } \\
\text { fair. }\end{array}$ & & & & & \\
\hline 6 & $\begin{array}{l}\text { In public libraries, career decisions are made by the } \\
\text { administrators in a non-judgmental manner. }\end{array}$ & & & & & \\
\hline 7 & $\begin{array}{l}\text { My administrator makes sure that the opinions of all } \\
\text { librarians are heard before making career decisions. }\end{array}$ & & & & & \\
\hline 8 & $\begin{array}{l}\text { My administrator collects accurate and complete } \\
\text { information in order to make career decisions. }\end{array}$ & & & & & \\
\hline 9 & $\begin{array}{l}\text { My administrator clarifies the decisions made and } \\
\text { provides additional information to librarians if needed. }\end{array}$ & & & & & \\
\hline 10 & $\begin{array}{l}\text { In public libraries, all occupational decisions are made } \\
\text { equally with regard to the librarians involved. }\end{array}$ & & & & & \\
\hline 11 & $\begin{array}{l}\text { Public libraries allow librarians to question or appeal to } \\
\text { administrators' decisions. }\end{array}$ & & & & & \\
\hline 12 & $\begin{array}{l}\text { When decisions are made about my job, the library } \\
\text { administrator treats me kindly. }\end{array}$ & & & & & \\
\hline 13 & $\begin{array}{l}\text { When decisions are made about my job, the library } \\
\text { administrator treats me with respect and competence. }\end{array}$ & & & & & \\
\hline 14 & $\begin{array}{l}\text { When decisions are made about my job, the library } \\
\text { administrator is sensitive to my personal needs. }\end{array}$ & & & & & \\
\hline 15 & $\begin{array}{l}\text { When decisions are made about my job, the library } \\
\text { administrator treats me honestly. }\end{array}$ & & & & & \\
\hline 16 & $\begin{array}{l}\text { When decisions are made about my job, the library } \\
\text { administrator shows interest in my rights as a librarian. }\end{array}$ & & & & & \\
\hline 17 & $\begin{array}{l}\text { When decisions are made about my job, the } \\
\text { administrator discusses with me the repercussions of the } \\
\text { decisions I have made. }\end{array}$ & & & & & \\
\hline 18 & $\begin{array}{l}\text { When decisions are made about my job, the library } \\
\text { administrator provides sufficient justification for the } \\
\text { decisions made about my job. }\end{array}$ & & & & & \\
\hline 19 & $\begin{array}{l}\text { When decisions are made about my job, the library } \\
\text { administrator explains what is acceptable to me. }\end{array}$ & & & & & \\
\hline 20 & $\begin{array}{l}\text { The library administrator explains very clearly every } \\
\text { decision I make about my job. }\end{array}$ & & & & & \\
\hline
\end{tabular}

